\title{
The Main Problems Faced by Higher Vocational Education and the Countermeasures
}

\author{
Hua $\mathrm{Li}^{1, \mathrm{a}}$, Lina Zhou ${ }^{2, \mathrm{~b}}$ and Yueming Yuan ${ }^{3, \mathrm{c}^{*}}$ \\ ${ }^{1,2,3}$ College of engineering and technology, Jilin Agricultural University
}

Xincheng Street 2888, Jilin Agricultural University, Changchun, Jilin Province 130118, PR China

a1544543@163.com, cyym_jlu@163.com

* The Corresponding author

Keywords: Vocational education; Main problems; Countermeasures

\begin{abstract}
With the Vocational Education and Adult Education Division 2017 work points meeting, following the $2016 \mathrm{Xi}$ Jinping general secretary of vocational education important instructions, once again on the work of vocational education requirements, we can see that the prospects for the development of vocational education is good. However, there are still some problems in higher vocational education. This paper mainly analyzes the main problems in the development of vocational education, and puts forward corresponding countermeasures to help the development of vocational education in China.

2017 vocational education and continuing education work is the overall requirements of steady progress: to speed up the construction of modern vocational education system, stronger vocational, excellent work, bigger training, good job enlightenment, to build a more open and smooth talent growth "overpass". Service to be fine, close to the supply side of structural reform, to serve the implementation of major national development strategy; team to enter the smooth flow of school-enterprise personnel two-way flow channels, improve vocational institutions and teachers training system, building a high level of "double Teacher type "teacher team [1].This is the general guideline for the future development of vocational education. However, in the course of the development of vocational education, it is necessary to move from the system to the form in order to move towards the general direction. In order to fundamentally promote the development of vocational education.
\end{abstract}

\section{The Main Problems and Causes of Higher Vocational Education}

The Relevant Laws and Regulations are not Perfect, the National Policy is not in Place: Although the "People's Republic of China Vocational Education Law" has been promulgated in 1996, the higher vocational education has particularity and the lack of the Higher Vocational Education Law has caused a lot of problems. For example, the nature of the higher vocational education, status, role, training objectives, personnel training mode, funding sources are lack of clear provisions, which led to the actual operation of the process of difficulty ${ }^{[2]}$.In the national policy, although the National Vocational Education and Adult Education Division is responsible for the development of vocational education, but the introduction of vocational education to support the development of enrollment, infrastructure and capital and other aspects of the relevant policies is one of the few. In 2014, the "modern vocational education system construction plan" (2014-2020), a number of issues related to vocational education requirements, but still did not rise to the legal status, so in the development of vocational education laws and regulations are not perfect, National policy is not in place.

Social Concept Obsolete, Lack of Identity for Vocational Education. Although the country's attention and attention to vocational education is getting higher and higher, but still in the development process there are some conceptual bias. The community is still generally considered higher vocational education is "poor education", that only the entrance of the so-called colleges and universities, "poor students" will choose the education, and even that higher vocational education is worse than the specialist. In the people's ideas in the prevalence of "heavy general education 
vocational education", "heavy academic light application" and other ideas of the error. These erroneous ideas have greatly hindered the development of higher vocational education and brought impact to cultivate applied talents.

Difficult to Enroll Students, Poor Convergence in Higher Vocational Education. At present, there are three main forms of convergence in China's higher vocational education: one is the secondary enrollment, mainly including secondary school, technical school and vocational school, mainly for the completion of vocational school students and vocational colleges through the separate organization of higher vocational entrance examination Students can go to the vocational college counterparts or similar professional to continue to learn. Second, the " $3+2$ " form, that is, by vocational colleges and secondary vocational schools, the implementation of sub-through-type joint school; three is a five-year system, is organized by five years of vocational colleges from the new Junior high school graduates in the recruitment, through the same secondary school entrance examination into the higher vocational colleges, school system for 5 years ${ }^{[3]}$. However, in the three higher levels of higher vocational education and secondary vocational education in the management of the split pattern, resulting in the failure to effectively link, so in 2011 the Ministry of Education, Vocational Education and Adult Education Division has issued "Ministry of Education on the promotion of medium And the higher vocational education coordinated development of the guidance "and" Ministry of Education on promoting higher vocational education reform and innovation to lead the development of vocational education, a number of opinions ", proposed to link the issue of secondary vocational education to the country to accelerate the transformation of economic development and Improve the people's livelihood of the urgent requirements, increase secondary vocational school graduates enrollment ratio.

the Infrastructure is Behind and the Funds Are Tight. In the 2014 Work Conference on the Development of Vocational Education, the General Secretary clearly stated that "vocational education shoulders important responsibilities to cultivate diversified talents, inherit technical skills and promote employment and entrepreneurship. "One of the goals of the development of vocational education is to cultivate applied and skilled talents. Therefore, the need for vocational education colleges and universities to provide students with adequate machinery and equipment to help students practice production. However, the status quo is that many areas of higher vocational education are from the original secondary schools and vocational schools merged, the teaching scale of teaching equipment is poor; in terms of funding, whether it is funding for education funding, or special funds, Whether it is capital investment, or matching funds in place ${ }^{[4]}$, there are problems with the school in primitive conditions, even debt, seriously affected the enthusiasm of running higher vocational teaching staff training, influence the application of Higher Vocational and technical personnel.

Unreasonable Curriculum, Lack of Characteristics, Practical Training Difficult. At present, China's higher vocational schools and the market is not close enough, there is education and market demand out of touch; professional curriculum set up, school model is not flexible; teaching content, teaching methods behind the old; theory and practice is not close, Timely update the course content and teaching methods ignore the teaching and research work, many teachers on the production and social practical understanding is not enough, the lack of practical experience, professional skills and practical ability is not strong ${ }^{[5]}$.In the student practice training stage, higher vocational colleges and related enterprises do not cooperate with each other, can not provide students with professional degree related business units for effective practice training, which is not conducive to the development of student skills.

The Construction of Higher Vocational Education Teachers Needs to be Strengthened. In order to cultivate the application type and the skill type and the talented person, the teacher who needs the vocational education in addition to constantly strengthen their own basic theoretical knowledge, the more is to cultivate his own practical ability, so that the teacher becomes the "double teacher" teacher, Type "is not equal to" double card type "teachers, and now in the higher vocational colleges, many teachers are only" double card ", in practice teaching is far from compliance, far behind the same industry technical staff. 


\section{The Countermeasures for Higher Vocational Education.}

With the higher vocational education by the community more and more attention and attention, in the rapid development of the same time, the emergence of some problems, if not resolved in time, will affect the development of vocational education, and even restrict the development of China's economic society. Therefore, the solution to the above problems is imminent.

The Establishment of Higher Vocational Institutions to Improve the Legal System, Improve the Functions of Party Committees and Governments at All Levels. Laws and policies are two means of national macroeconomic regulation and control. For a long time, the management of higher vocational education in our country has been achieved through policy regulation, thus ignoring the role of law. In China, higher vocational education-related laws only "Education Law of the People's Republic of China", "Higher Education Law of the People's Republic of China" and "People's Republic of China Vocational Education Law" and so on. Generally speaking, the law for higher vocational education is relatively small, the need for our Ministry of Education, especially vocational education and adult education division of this targeted sector with the nature of higher vocational education, school characteristics and other legal development, in addition, the level of the party committees and governments at all levels should also clear responsibilities, combined with the specific circumstances of the local, strong support for the development of vocational education, so that higher vocational education to do a real law.

Change the Traditional Concept, a Clear Positioning of the School. First of all, to clarify the strategic position of higher vocational education, in 2014, vocational education and adult education work conference, General Secretary Xi Jinping said: "Vocational education is the national education system and an important part of human resources development, To an important way to successfully enter the door, vocational education shoulders a variety of talent, inheritance of technical skills, to promote employment important responsibilities. Therefore, to change the traditional concept of "re-education and education", the state and society should increase the propaganda and breadth of vocational education, and provide a good environmental basis for the development of higher vocational education. Secondly, Vocational colleges to strengthen their own internal institutions, will develop technical and applied talents as their own school characteristics, a clear school orientation.

To Create a Variety of Forms of Investment Mechanism, Strengthen the Basic Set Up Construction, Improve School Conditions. First of all, to increase the government's direct investment in higher vocational education, China's current vocational colleges are mostly organized by the government or funded, therefore, governments at all levels should fulfill their duties, continue to increase investment in higher vocational colleges, Poor infrastructure facilities, lack of laboratory equipment and other issues; Second, under the government's macro-control, to encourage enterprises to participate in higher vocational education, in the course of running, to take the government "first guide, after the autonomy" principle, to help enterprises to participate in vocational schools, the country according to business participation The capital cost and the teaching resources of the higher vocational education school, take the corresponding policy financial subsidy or tax relief and other policies to safeguard the interests of enterprises, thus to a certain extent, promote enterprises and higher vocational colleges to stabilize and win, And thus promote the normalization of school-enterprise cooperation. From the nature to improve the conditions of running higher vocational colleges, will be the national higher vocational education to bring prosperity.

According to the Requirements of the Market, a Reasonable set of Vocational Courses, Optimize the Professional Settings. Today's society is the information society, which also requires our vocational education to carry out the information system system, in 2015, vocational education and continuing education work points, clearly defined the construction of "vocational school digital campus construction norms" for the occupation Education provides digital resource management and learning platform construction. Therefore, according to the needs of the market, relying on market demand and job development needs, reasonable adjustment of personnel training direction, follow the law of education and market economy, to find the best combination of points, so that 
personnel training objectives and industry, business, social development ${ }^{[1]}$. Strengthen the basic theory of education to help students improve their comprehensive ability, at the same time based on the characteristics of higher vocational schools to improve the experimental, internship and skills training courses such as columns, so as to optimize the professional settings, easy to develop students into a technical compound type talent.

To Strengthen the Construction of Teachers, Increase the Proportion of Part-time Teachers. The teachers of higher vocational colleges to provide a certain scale, the number of levels of on-the-job training, so as to improve the professional quality of teachers and theoretical learning level. There are plans to implement the backbone of the teacher training program to strengthen the professional level of professional knowledge of teachers to promote the training of key teachers, and thus enhance the professional quality of teachers. In addition, we should rationally plan the teacher's job evaluation system. government, schools to provide teachers with the appropriate job title for the conditions, to encourage teachers to actively declare. Higher vocational school part-time teachers is a bridge between schools and society, is the school's new professional growth point ${ }^{[6]}$. The major vocational colleges should be based on their own schools and the professional needs of the market to determine the needs of part-time teachers in the proportion of teachers in the school. You can through the guest lectures, part-time professors and professional consultants and other forms of employment in all walks of life of all walks of life have rich experience of talent, rich vocational college teachers.

\section{References}

[1] http://www.moe.edu.cn/jyb_xwfb/gzdt_gzdt/moe_1485/201703/t20170322_300384.html

[2] Liu Haixia, China's higher vocational education development problems and countermeasures [D]. Qingdao: Qingdao University .2008.

[3] Wang Long; Wu Lei; Ding Ligang; Feng Chang. The problems of convergence in higher vocational colleges and their countermeasures [J]. Higher Education Forum .2015: 35-37.

[4] Su Baofang; Cao Zhiqing. The main problems in the development of higher vocational education and countermeasures[J].. Education Exploration, 2004, (8): 52-54.

[5] Zhang Qin. China's higher vocational education problems and countermeasures [J]. Journal of Zhengzhou Railway Vocational and Technical College .2014, (26): 33-34.

[6] Ji Fei, Guizhou Province, higher vocational and technical education development and countermeasures [D] .Guiyang, Guizhou University, 2008. 